\title{
Evaluation of methods for estimating daily reference crop evapotranspiration at a site in the humid alpine meadow, northeastern Qinghai-Tibetan Plateau
}

\author{
Licong Dai ${ }^{1}$, Ruiyu $\mathrm{Fu}^{2}$, Xiaowei Guo ${ }^{1}$, Yangong Du ${ }^{1}$, Fawei Zhang ${ }^{1}$, Yikang $\mathrm{Li}^{1}$, and \\ Guangmin $\mathrm{CaO}^{1}$ \\ ${ }^{1}$ Northwest Institute of Plateau Biology Chinese Academy of Sciences \\ ${ }^{2}$ Nanjing Normal University
}

October 26, 2020

\begin{abstract}
Evapotranspiration as the key component of the terrestrial water cycle, an accurate estimates of evapotranspiration are of great importance for water irrigation management. Although many applicable ET models have been developed, these are largely focused on low altitude regions, with little attention to alpine ecosystem. In this paper, we evaluate the performance of 14 evapotranspiration (ET0) models by comparison with large weigh lysimeter measurements. Specifically, we use Bowen ratioenergy balance method, three combination models, seven radiation-based models and three temperature-based models driven with data from June 2017 to December 2018 in a humid alpine meadow, northeastern Qinghai-Tibetan Plateau. The daily actual evapotranspiration was obtained by large weighing lysimeters located in an alpine Kobresia meadow. We found that the performances of the 14 ET0 models, ranked on the basis of their RMSE (root mean square error), decreased in the order: Bowen> Priestley-Taylor $>$ DeBruin-Keijman $>1963$ Penman $>$ FAO-24 Penman $>$ FAO-56 Penman-Monteith $>$ IRMAK1 $>$ Makkink (1957) $>$ Makkink(1967) $>$ Makkink $>$ IRMAK2 $>$ Hargreaves $>$ Hargreaves1 $>$ Hargreaves2. For the combination models, FAO24 Penman yielded the highest correlation, followed by Pen-63 and FAO-56 PM. For radiation-based models, PT and DK obtained the highest correlation, followed by Makkink, Makkink(1967) and Makkink (1957), IRMAK1 and IRMAK2. For temperaturebased models, HAR, HAR1 and HAR2 obtained the same correlation. Overall, the Bowen performed best, with RMSEs 0.98, followed by radiation-based models, combination models and temperature-based models. Furthermore, all models tended to underestimate measured ETa during periods of larger evaporative demand (i.e. growing season) and overestimate measured ETa during lower evaporative demand (i.e. non-growing season). Our results could provide a new sight for the accurate assessment of evapotranspiration in an alpine ecosystem.
\end{abstract}

\section{Hosted file}

manuscript2.pdf available at https://authorea.com/users/285508/articles/488993-evaluationof-methods-for-estimating-daily-reference-crop-evapotranspiration-at-a-site-in-thehumid-alpine-meadow-northeastern-qinghai-tibetan-plateau

\section{Hosted file}

Figure.pdf available at https://authorea.com/users/285508/articles/488993-evaluation-ofmethods-for-estimating-daily-reference-crop-evapotranspiration-at-a-site-in-the-humidalpine-meadow-northeastern-qinghai-tibetan-plateau

\section{Hosted file}


Table.pdf available at https://authorea.com/users/285508/articles/488993-evaluation-ofmethods-for-estimating-daily-reference-crop-evapotranspiration-at-a-site-in-the-humidalpine-meadow-northeastern-qinghai-tibetan-plateau 